\title{
Internal Determinants and Effects of Firm-Level Environmental Performance: Empirical Evidences from Vietnam
}

\author{
Pham Quynh Anh ${ }^{1}$ \\ ${ }^{1}$ University of Economics and Business, Vietnam National University, Hanoi, Vietnam \\ Correspondence: Pham Quynh Anh, University of Economics and Business, Vietnam National University, Room \\ 309, Building E4, 144 Xuan Thuy Road, Cau giay District, Hanoi, Vietnam. E-mail: anhpq@vnu.edu.vn
}

Received: September 23, 2014 Accepted: November 17, $2014 \quad$ Online Published: January 14, 2015

doi:10.5539/ass.v11n4p190

URL: http://dx.doi.org/10.5539/ass.v11n4p190

\begin{abstract}
The paper explores the internal determinants of a manufacturing firm's environmental performance indexed by acquiring government or ISO 14001 certificate and its impacts on the firm's competitiveness in Vietnam, using a panel logistic and a modified Cobb-Douglas model respectively. It is found that firm size; environmental management system (EMS), foreign ownership, environmental staff, high technology level and middle age are factors increasing a firm's possibility conforming to the ISO 14001 standards while domestics' private ownership and low-or medium technology levels are constraints. There is no conclusive relationship between firm's environmental performance, state ownership and old, young age. Firm's environmental performance has no significant impact on its competitiveness measured by labor productivity.
\end{abstract}

Keywords: environmental performance, pollution reduction, environmental management system, government environmental certificate, ISO 14001 certificates, firm's competitiveness

\section{Introduction}

The implementation of the open-door policy since the late 1990s has led to dramatic economic changes in Vietnam, characterized by flows of foreign direct investment, an explosion of newly established private domestic firms and the acceleration of industrialization. Manufacturing sector's gross output as well as value-added has achieved relatively high annual growth rates of 10-12 percent during 1991-2008, except the Asian financial crisis year of 1998. Nevertheless, like many other industrializing countries, green growth has been a crucial challenge for manufacturing firms and the entire economy in Vietnam. Annual environmental survey (GSO, 2009) indicates that only around one-third of manufacturing firms had expenditures on pollution reduction. The most recent investigation conducted by the Environmental Police Department (National Center for Socio-Economic Information and Forecast, 2014) revealed polluted fluid flowing direct to environment from two-third of 232 industrial zones, account for approximately 40 percent of Vietnam's total industrial output.

The serious pollution has stimulated growing studies on environment problem in Vietnam, most of which, however, approach this from a technical view, focusing on emission magnitude and its impacts on living conditions of community as well as technology solutions to problem. There has been a research gap with few studies investigating the relationships between pollution and economic and management factors that are founded by number of researches as the most important for pollution reduction in developing countries (Dasgupta, Hettige, \& Wheeler 2000; Ruiz-Tagle, 2006). This paper is, therefore, the first to identify the determinants of firm-level environmental performance and its impact on manufacturing firms' competitiveness in Vietnam from the management and economic perspectives, especially using advanced econometric analysis method and panel data. Additionally, the paper contributes to world-wide environment-related literatures in highlighting internal factors that affect firm-level environmental performance indexed by achieving ISO 14001certification and examining its impact on firm's competitiveness measured by productivity.

The paper is organized as follows. The next session reviews background studies and demonstrates conceptual framework. Session 3 explains data and research methods. Session 4 presents and discusses research results on characteristic, internal determinants of manufacturing firm's environmental performance and its impact on firm' competitiveness. The last session-session 5 summarizes the research findings and gives relevant policy implications. 


\section{Background Studies and Conceptual Framework}

\subsection{Definition and Measure of Environmental Performance}

Environmental performance has attracted a substantial amount of studies over the world since the 1990s. Despite this concept's importance to sustainable development, it is perceived differently among literatures and not often defined clearly. The definition of environmental performance, as summed by E. Lefebvre, L. Lefebvre and Talbot (2003), ranges from a simple perception as a certain environmental activity, to a "fuzzy" concept. Between two these extremes, environmental performance is termed by numerous researchers as environmental responsiveness or results or both that in turn are examined multi-dimensionally from a single aspect or different combinations of technical, social, economic and management terms, at firm-, industry-, zone- or national level. Nonetheless, all environmental performance definitions imply a common point which is pollution reduction. Consequently, based on its definition and conditions for environmental data collection, environmental performance is measured directly by emission volume (Porter \& Linde, 1995), ratio of emission over output level (Earnhart \& Lizal, 2007, Arimura, Hibiki, \& Katayama, 2008), emission intensity (Jiang \& Lin, 2014). This was also indirectly measured by degree of environmental regulation compliance (Dasgupta et al., 2000), an overall score based on firm's valuation of its environmental management and environmental control and ecological material, product (Clausen, Keil, \& Conrard, 2002), the firm's product life management score and intention to apply EMS in line with ISO 14001(Lefebvre et al., 2003), government discharge of over-standard pollution per output level (Wang \& Jin, 2007); level of energy usage (Cole, Elliott, \& Strobl, 2008), the firm's managers assessment of its positions based on emission reduction (Lopez-Gamero, Molina-Azorin, \& Clave-Cortes, 2009).

Given the limits in access to direct data on pollution and corresponding output, this study terms a firm's environmental performance as the pollution control success at either one or both of two levels, by government or international environmental management standards-ISO 14001. This adoption is attributed firstly to comprehensive standards of environmental management system for firms to be certified by government or ISO 14001, which comprises of planning quantifiable pollution abatement targets, selecting the least available pollution- causing technology, reviewing the implementation progress and making essential adjustments. In addition, although ISO 14001 is set by a voluntary international organization, it requires registered firms to comply with domestic environmental laws, regulations and other detailed documentations. Secondly, numerous empirical studies, as summarized by Potoski and Prakash (2013), proved that applying ISO 14001 standards led to considerable pollution reduction. According to Commission for Environmental Cooperation (2005), there were substantial decreases in emission magnitudes, even up to 60 percent, for numerous firms practicing ISO 14001 in North America. It is also widely recognized that, compliance with government environmental regulations also limits pollution albeit the level is likely lower than by the ISO 140001 criteria since according to Prakash and Potoski (2006), there are evidences that environmental program of firms adopting ISO 14001 exceed those required by government requirements.

\subsection{Factors Affecting Environmental Performance}

Environmental performance is logically determined by differential factors that are categorized into the external and the internal (Hojat, Rahim, \& Chin, 2011). The former refers to state law, regulations and inspectors that act as the pressures on firms to undertake pollution abatement activities. The latter is a firm's owned factors comprising firm size, ownership status, regular financial and human resources for operating pollution abatement, environmental management system and the volume and types of emission. The internal factors are, therefore, firms' own features and play as the essential conditions for them to reduce pollution.

In order to obtain ISO 140001 certificate a firm must meet the number of critical requirements. The primary is the ISO 14001 registered cost of approximate US $\$ 50000$ for the small firms and more than US $\$ 1$ million for the large system, including the cost to establish EMS, which is initially audited, and then annually recertified (Potoski \& Prakash, 2006). Such a high cost is a crucial barrier for firms in many developing countries like Vietnam where a considerable portion of firms has total stock of capital merely approximating this ISO cost. A range of empirical works (Dasgupsta et al., 2000; Arimura et al., 2007; Khanna, Deltas, \& Harrington, 2008) also supports a proposition that firm size, measured by capital or labor, substantially increases firm's investment and success in pollution control. Large firm's gain economy of scale in not only production but also environment activities (Shadbegian \& Gray, 2006)

The impacts of other characteristics of a firm including ownership, age, technology level of industry in which it operates are also examined by several studies. In a transition economy, firm ownership status is a potential predictor for environmental performance. Empirical studies by Wang et al. (2003), Earnhart and Lizal (2007) 
Cole (2008), Jiang et al. (2014) found the positive impact from foreign ownership which was argued to have available resource of finance, more advanced technology and greening culture. In contrast, foreign firm was supposed to have negative effect since they received little welfare benefits from host country (Nakamuka, Takahashi, \& Vertinsky, 2001), or a certain percentage of these firms came from developing countries that had less stringent environmental regulations (Mabey \& McNally, 1999). Regarding firm age and industry in which a firm operates, the study by Shadbegian and Gray (2006) reveals that older firms area less productive and more costly than young firms in pollution abatement. Firm environmental performance is also industry-specific and those operating in high-tech sector are less polluted than the others (Lefebvre et al., 2003).

In terms of environmental activities, the establishment and operation of EMS is apparently a core condition for a firm to be environmentally qualified whether by national or international standards. Dasgupsta et al. (2000) found that in line with firm size, EMS is one of the most important determinants for environmental compliance or pollution control degree. Similarly, being governmentally qualified in terms of environmental protection or passing the national level test is a logical preparation for passing the examination at the international level.

\subsection{The Impact of Environmental Performance on Firm Competitiveness}

This relationship is an important research issue since both competitiveness and environmental performance are contemporary pillars for all countries' sustainable development in the increasingly globalizing world economy. There have been increasing studies on this interesting relationship but their results were not convergent. This is apparently attributed to existing marked variations in definition and measure of both dependent and independent variables, or due to the lack of strong theoretical foundation as explained by Lopez-Gamero et al. (2009). Like environmental performance, firm-level competitiveness is viewed as a "flexible and diffuse" concept (Lall, 2003), and varying across literatures. It is termed as productivity by Porter (1990, 1998), Hitchens (2001), Clausen et al. (2002). In addition, this concept is measured in export extent, change in employment and profitability by Clausen et al. (2002), or high revenue, profit by Lefebvre et al. (2003) or low price, product differential by Lopez-Gamero et al. (2009). All these measures of competitiveness, however, directly or indirectly affect a firm's ability to compete successfully in the market. In this study, competitiveness is indexed by labor productivity as analyzed by Porter $(1990,1998)$.

Porter and Linde (1995) argued that stringent environmental regulations led to innovation which consequently improved environmental performance (reduced emission) and competitiveness. This is named as Porter's hypothesis (HP) which contradicts to the normal view of detracting investment cost from environmental protection cost and therefore stimulates the test of numerous theoretical and empirical studies. Ambec, Cohen, Elgie and Lanoie (2011) overviewed 28 HP examining works of which 13 papers directly analyzed the effect of environmental compliance on firm competitiveness. The results were mixed with five indicating negative impacts, six revealing direct or indirect positive and two reporting the conclusive. Hinchens (2001) reviewed a large number of studies on the impact of environmental management caused by government regulations in OECD countries, also summarized that there was no evidence of negative impact on firm competitiveness. Cohen et al. (2002) generalized the interviewees' opinions, reporting that environmental legislation reduced competitiveness in two industries being furniture, fruit and vegetable but increased competitiveness in the textile. The study by Lopez-Gamero et al. (2009) also demonstrated insignificant environmental performance's impact on competitiveness, while the studies of Lefebvre et al. (2003) using simple Pearson correlation, founded contradictory results of this relationship between some manufacturing industries.

\section{Data and Methodology}

\subsection{Data}

Data are attracted from the annual survey on all enterprises conducted by Vietnam General Statistical Office (GSO) with technical as well as financial assistance from the World Bank. Although most of this survey cover population of firms operating within all economic sectors in Vietnam and had been available since the year 2000 up to present, the environmental part consists of a small proportion of firms, undertaken from 2004 to 2009 and provided adequate information for this study in only the three last years (2007, 2008 and 2009). Nonetheless, the environmental sample was designed to ensure representativeness for manufacturing firms in terms of all principle aspects such as ownership, size, industry and province. After deleting observations that were not completely identical in all the three years and offered no essential information for research purposes, there were two types of data, panel and cross-session left.

The panel comprises of 3036 observations, constructed from 1012 firms surveyed in three consecutive years of 2007, 2008 and 2009. The total number of observations in the panel is smaller than that in the cross-session data of the year 2009. However, as panel data has numerous advantages over to one-dimension data (cross session or 
time-serial), especially in identifying and measuring effects, the former is selected as the underlying in this study to identify characteristics and to investigate the determinants of firm-level environmental performance in Vietnam.

The cross-session includes two sets. The first contains 4979 observations in 2009, employed as the supplementary for the panel-based regression on determinants of firm-level environmental performance. The second consists of 515 observations also in 2009, used to investigate the impact of a firm's environmental performance on its competitiveness.

\subsection{Methodology}

First, based on statistical description of the mentioned cross-session data, the comparative analysis method is used to identify characteristics of firm-level environmental activities and performance across ownership, industry and size. Second, econometrics analysis is conducted based on two models. The first is a logistic model as dependent variable is a dummy, used to investigate internal factors affecting environmental performance and theirs extent of effect. The second is a specification modified from the well-known Cobb-Douglas function, which is employed to examine the impact of a firm's environmental performance on its competitiveness.

Model 1:

$$
E P=f(O W N, S I Z, I N D, A G E, E A)
$$

Table 1. Description of detailed variables of the model 1

\begin{tabular}{ll}
\hline Variables & Description \\
\hline Dependent & \\
EP1 & 1 if firm was environmentally certified by government, 0 otherwise \\
EP2 & 1 if firm was environmentally certified by ISO 14001, 0 otherwise \\
Explainable & \\
OWN & Ownership types \\
SOE & 1 if firm is state-owned enterprises, 0 otherwise \\
NSOE & 1 if firm is non-state-owned enterprises, 0 otherwise \\
FIE & 1 if firm is foreign invested enterprises, 0 otherwise \\
SIZ & Firm size \\
LOGCAP & Logarithm of firm's total stock capital \\
IND & Industry groups \\
LOWG & 1 if firm operates in a low-technology industry; 0 otherwise \\
MEDG & 1 if firm operates in a medium-technology industry ; 0 otherwise \\
HIGHG & 1 if firm operates in a high-technology industry; 0 otherwise \\
AGE & Period in which firm was established \\
OLD & 1 if firm was established before $1990 ; 0$ otherwise \\
MID & 1 if firm was established between $1990-2000 ; 0$ otherwise \\
YOUNG & 1 if firm was established after 2000; 0 otherwise \\
EA & Environmental activities \\
EPER & Number of environmental personnel \\
EMS & 1 if firm has environmental management system; 0 other wise \\
\hline
\end{tabular}

Note: LOWG comprises of industries from D15 to D19; MEDG comprises of industries from D20 to D27; HIGHG comprises of industries from D 28 to D 37, according to two-digit ISIC (International Standard Classification), Revision3.

Model 2:

$$
\log (Y / L)=\beta_{0}+\beta_{1}(K / L)+\beta_{2} \log (W / L)+\beta_{3} X+u
$$

$\mathrm{Y}$ is total value-added created by firm, $\mathrm{L}$ is the total number of employee, $\mathrm{K}$ is the total fixed asset value, $\mathrm{W}$ is the total wage of all employees, $\mathrm{X}$ is the vector of other potential factors affecting labor productivity including 
firm's environmental performance, ownership, industry group in which firm operates as described in model $1, \mathrm{u}$ is error term.

LOGPRO denotes logarithm of productivity, LOGFIXCAP denotes the total fixed asset value per employee, LOGSKILL denotes logarithm of wage per employee, EPi is either EP1 or EP2. As a result, the equation (2) can be expressed as equation (3) below.

$$
\begin{aligned}
& L O G P R O=\alpha_{0}+\alpha_{1} L O G F I X C A P+\alpha_{2} L O G S K I L L+\alpha_{3} S O E+\alpha_{4} N S O E+\alpha_{5} F I E \\
& +\alpha_{6} L O W G+\alpha_{7} M E D G+\alpha_{8} H I G H G+\alpha_{9} E P i+u
\end{aligned}
$$

\section{Research Results}

\subsection{Characteristics of Firm Size, Environmental Activities and Performance by Ownership, Industry and Age}

Table 2 demonstrates the statistical description of mean value of firm size, environmental activities and performance of manufacturing firms by ownership sector, industry group and age in Vietnam within the three-year period of 2007-2009. The first striking characteristic is poor environmental performances, especially by ISO 14001 standards as the whole and across all sector ownerships, industry groups and age ranges with more than half of the firms being the private, young, low-technology.

Table 2. Characteristics of firm's size, environmental activities and performance by ownership sector, industry

\begin{tabular}{|c|c|c|c|c|c|c|}
\hline Firm feature & $\begin{array}{l}\text { Firm } \\
\text { number }\end{array}$ & CAP & EPER & EMS & EP1 & EP2 \\
\hline \multicolumn{7}{|c|}{ Ownership types } \\
\hline SOE & 325 & $\begin{array}{l}580 \\
(1191)\end{array}$ & $\begin{array}{l}3.08 \\
(4.47)\end{array}$ & $\begin{array}{l}0.67 \\
(0.47)\end{array}$ & $\begin{array}{l}0.55 \\
(0.5)\end{array}$ & $\begin{array}{l}0.16 \\
(0.37)\end{array}$ \\
\hline NSOE & 1748 & $\begin{array}{l}89.9 \\
(367)\end{array}$ & $\begin{array}{l}1.51 \\
(3.79)\end{array}$ & $\begin{array}{l}0.41 \\
(0.49)\end{array}$ & $\begin{array}{l}0.4 \\
(0.49)\end{array}$ & $\begin{array}{l}0.07 \\
(0.25)\end{array}$ \\
\hline FIE & 963 & $\begin{array}{l}315 \\
(828)\end{array}$ & $\begin{array}{l}2.2 \\
(4.21)\end{array}$ & $\begin{array}{l}0.59 \\
(0.49)\end{array}$ & $\begin{array}{l}0.61 \\
(0.49)\end{array}$ & $\begin{array}{l}0.19 \\
(0.4)\end{array}$ \\
\hline \multicolumn{7}{|c|}{ Industry groups } \\
\hline LOWG & 1216 & $\begin{array}{l}236.6 \\
(811)\end{array}$ & $\begin{array}{l}2.27 \\
(4.92)\end{array}$ & $\begin{array}{l}0.5 \\
(0.5)\end{array}$ & $\begin{array}{l}0.47 \\
(0.5)\end{array}$ & $\begin{array}{l}0.09 \\
(0.29)\end{array}$ \\
\hline MEDG & 1057 & $\begin{array}{l}202.9 \\
(615)\end{array}$ & $\begin{array}{l}1.77 \\
(3.51)\end{array}$ & $\begin{array}{l}0.51 \\
(0.5)\end{array}$ & $\begin{array}{l}0.49 \\
(0.5)\end{array}$ & $\begin{array}{l}0.11 \\
(0.32)\end{array}$ \\
\hline HIGHG & 764 & $\begin{array}{l}191.9 \\
(535)\end{array}$ & $\begin{array}{l}1.48 \\
(3)\end{array}$ & $\begin{array}{l}0.48 \\
(0.5)\end{array}$ & $\begin{array}{l}0.48 \\
(0.5)\end{array}$ & $\begin{array}{l}0.17 \\
(0.37)\end{array}$ \\
\hline \multicolumn{7}{|l|}{ Age ranges } \\
\hline OLD & 265 & $\begin{array}{l}638.1 \\
(1354)\end{array}$ & $\begin{array}{l}3.41 \\
(6.46)\end{array}$ & $\begin{array}{l}0.67 \\
(0.47)\end{array}$ & $\begin{array}{l}0.58 \\
(0.49)\end{array}$ & $\begin{array}{l}0.14 \\
(0.35)\end{array}$ \\
\hline MID & 1056 & $\begin{array}{l}244.8 \\
(553)\end{array}$ & $\begin{array}{l}2.15 \\
(4.31)\end{array}$ & $\begin{array}{l}0.54 \\
(0.5)\end{array}$ & $\begin{array}{l}0.52 \\
(0.5)\end{array}$ & $\begin{array}{l}0.16 \\
(0.37)\end{array}$ \\
\hline YOUNG & 1716 & $\begin{array}{l}128.9 \\
(575)\end{array}$ & $\begin{array}{l}1.51 \\
(3.24)\end{array}$ & $\begin{array}{l}0.44 \\
(0.5)\end{array}$ & $\begin{array}{l}0.44 \\
(0.5)\end{array}$ & $\begin{array}{l}0.08 \\
(0.28)\end{array}$ \\
\hline Total & 3037 & $\begin{array}{l}\mathbf{2 1 3 . 6} \\
(688)\end{array}$ & $\begin{array}{l}1.97 \\
4.04\end{array}$ & $\begin{array}{l}\mathbf{0 . 4 9} \\
(0.5)\end{array}$ & $\begin{array}{l}\mathbf{0 . 4 8} \\
(0.5)\end{array}$ & $\begin{array}{l}\mathbf{0 . 1 2} \\
(0.32)\end{array}$ \\
\hline
\end{tabular}
group, age ranges within the 2007-2009 period

Source: Author's own calculation based on GSO firm-level environmental survey. Note: CAP-total stock capital of a firm

The average score for number of firms establishing EMS and acquiring environmental certification from government is 0.49 and 0.48 correspondingly, constituting slightly approximate 50 percent of total firms (Note 1), and the respective figures by ISO 14001 were very low, merely 0.12 and 12 percent. The total number of ISO 
14001-certified firms was only around close to 20 percent for the least polluting firms by ownership type or industry group or age range. Less than half of NSOE or young firms did not establish EMS and were unable to meet national environmental standards. Of the most polluting firm ownerships, collective and private, (see appendix 1.1) only one-fifth were environmentally qualified by government and even no firm being qualified by international environmental standards. Notably, the proportions of firms being environmentally qualified by government across ownership, industry and age were 3-5 times to those by ISO 14001, demonstrating substantially lower environment standards in Vietnam in relation to international level.

Secondly, there still emerged considerable disparities in average firm size and environmental performance between sector and especially firm ownerships despite their generally poor environmental performance or in other words, firm's environmental performance is ownership- specific. The average size of SOE was approximate to 7 times larger than NSOE virtually being small and medium-sized (SME). The number of FIE receiving ISO 14001 certificate was still about 2.5 times as large as by NSOE and this gap was up to 23 times between the joint-venture FIE with state firms and the collective, private (appendix 2.1). The NSOEs accounted for approximating 60 percent of total number of firms in this surveyed sample and about 70 percent of the population of manufacturing (GSO, 2009). This explains in large part a dominant grey color of the environmental picture of manufacturing sector in Vietnam.

Thirdly, environmental activities and performances variations by industry or age were somewhat less significant than by ownership although the marked differentials in firm size emerged across age ranges with new firms being nearly five times smaller than the old. The firm operating in the basic-good, low-tech industry group had lower environmental activities as well as performances than those in the medium-tech, particularly in the high-tech industry group. This implies that environmental performance is possibly affected by industry technology level as the whole. In terms of age, the new and old firms appeared to come more polluting than the middle-aged. This was consistent to the fact that most of new firms were NSOE which were the most polluting and constitutes the largest share in this sample and in firm population in Vietnam as noted earlier.

\section{Regression Results and Discussions}

\subsection{Results}

\subsubsection{Model 1}

Table 3 reports results of the random panel logistic regressions on determinants of firm-level environmental performance (EP) at two levels, being environmentally government certified (EP1) or ISO 14001-certified (EP2). Virtually all significant coefficients regressed from the panel data between 2007-09 have similar signs to those from the cross-session data of 2009 and the former's magnitudes are somewhat larger and more significant than the latter.

The results reveal that coefficients of firm size on both levels of environmental performance are very statistically significant and positive, suggesting that the larger a firm is, the more likelihood it acquires environmental certifications. Firm size by capital is an important determinant especially of firm's possibility to be qualified by ISO 14001. Controlling the impacts from firm's characteristics except size, type of firm ownership affects variously on firm's possibility in obtaining environmental certificates. Foreign ownership variable is very statistically significant and has positive sign for either government or ISO14001 certifications, indicating that FIEs are most likely to meet national and international environmental requirements. The private and state ownership variables also have statistically significant but negative signs and the private is least likely to meet domestic as well as international environmental standards.

The technology levels of industry group in which firm operates also have significant and different influences on the firm's environmental performance at the international level. High-tech industry group reveals a positive predictor of firms being able to satisfy ISO 14001 standards while those in low-tech industries are less likely to meet such environment standards. Medium-tech industry group has no significant impact on firms at both national and international levels of environmental performance.

The age group variables affect firm's environmental performance less than the other. Of three age ranges, only the middle age significantly increases the firm's possibility of being ISO 14001 certified. The other two age ranges, the old and the young do not have significant impact on environmental performance at both levels.

All direct environmental activities variables in the model significantly and positively increase firm's possibility of being qualified by ISO14001. The number of environment staff positively and significantly increases firm's likelihood of acquiring environmental certifications. Similarly, EMS is the most important predictor of firm-level environment performance whether at national or international levels. 
The result indicated that acquiring government certifications strongly increases firm's possibility of obtaining ISO 14001 certificates These results suggest that meeting national pollution abatement requirements is an effective preparation for manufacturing firms to pursue and satisfy higher environmental criteria issued by international organizations. The pro-Child square equals zero, implying that the model is well defined (Note 2).

Table 3. Internal determinants of firm's environmental performance. Dependent variable: EP

\begin{tabular}{|c|c|c|c|c|}
\hline \multirow{2}{*}{ Explanatory variables } & \multicolumn{2}{|c|}{ Panel logistic result } & \multicolumn{2}{|c|}{ Cross-session logistic result } \\
\hline & EP1 & EP2 & EP1 & EP2 \\
\hline \multirow[t]{2}{*}{ LOGCAP } & $0.38^{* * *}$ & $0.83 * * *$ & $0.2 * * *$ & $0.32 * * *$ \\
\hline & $(0.52)$ & $(2.25)$ & $(0.22)$ & $(1.14)$ \\
\hline \multirow[t]{2}{*}{ SOE } & $-0.76^{* *}$ & $-0.88^{*}$ & 0.23 & 0.01 \\
\hline & $(0.3)$ & $(0.53)$ & $(0.16)$ & $(0.22)$ \\
\hline \multirow[t]{2}{*}{ NSOE } & $-0.79 * * *$ & $-1.2 * * *$ & $-0.22 * * *$ & -0.07 \\
\hline & $(0.19)$ & $(0.38)$ & $(0.06)$ & $(0.12)$ \\
\hline \multirow[t]{2}{*}{ FIE } & $0.73 * * *$ & $1.14 * * *$ & $0.55^{* * *}$ & $0.18^{*}$ \\
\hline & $(0.2)$ & $(0.37)$ & $(0.08)$ & $(0.12)$ \\
\hline \multirow[t]{2}{*}{ LOWG } & -0.01 & $-1.2^{* * *}$ & $0.13^{*}$ & $-0.19 * *$ \\
\hline & $(0.18)$ & $(0.38)$ & $(0.07)$ & $(0.12)$ \\
\hline \multirow[t]{2}{*}{ MEDG } & 0.01 & -0.15 & -0.07 & -0.06 \\
\hline & $(0.19)$ & $(0.38)$ & $(0.07)$ & $(0.1)$ \\
\hline \multirow[t]{2}{*}{ HIGHG } & 0.14 & $1.55^{* * *}$ & -0.08 & $0.3^{* *}$ \\
\hline & $(0.2)$ & $(0.4)$ & $(0.08)$ & $(0.12)$ \\
\hline \multirow[t]{2}{*}{ OLD } & -0.38 & -0.89 & na. & na. \\
\hline & $(0.33)$ & $(0.57)$ & & \\
\hline \multirow[t]{2}{*}{ MID } & 0.14 & $0.57^{*}$ & na. & na. \\
\hline & $(0.19)$ & $(0.38)$ & & \\
\hline \multirow[t]{2}{*}{ YOUNG } & 0.01 & -0.19 & na. & na. \\
\hline & $(0.18)$ & $(0.38)$ & & \\
\hline \multirow[t]{2}{*}{ EPER } & $0.09 * * *$ & $0.11 * * *$ & $0.07 * * *$ & $0.02 * * *$ \\
\hline & $(0.25)$ & $(0.03)$ & $(0.02)$ & $(0.01)$ \\
\hline \multirow[t]{2}{*}{ EMS } & $2.75^{* * *}$ & $2.83 * * *$ & $1.94 * * *$ & $2.7 * * *$ \\
\hline & $(0.17)$ & $(0.39)$ & $(0.07)$ & $(0.14)$ \\
\hline \multirow[t]{2}{*}{ EP1 } & & $3.11 * * *$ & & \\
\hline & & $(0.37)$ & & \\
\hline \multirow[t]{2}{*}{ Constant } & $-5.34 * * *$ & $-16.9 * * *$ & $-3.4 * * *$ & $-4.3 * * *$ \\
\hline & $(0.6)$ & $(1.58)$ & $(0.25)$ & $(0.17)$ \\
\hline Observations & 3036 & 3036 & 4919 & 4919 \\
\hline Wald $C h i^{2}$ & 367 & 126.7 & 1634 & 534.3 \\
\hline Prob $>C h i^{2}$ & 0 & 0 & 0 & 0 \\
\hline Log likelihood & -1503 & -660.2 & -2458 & -1143 \\
\hline Pseudo $R^{2}$ & & & 0.25 & 0.3 \\
\hline
\end{tabular}

Note: Level of significance *10\%;**5\%;***1\% 


\subsubsection{Model 2}

Table 4. The impact of environmental performance on firm's competitiveness. Dependent variables: LOGPRO

\begin{tabular}{llll}
\hline $\begin{array}{l}\text { Explanatory } \\
\text { variables }\end{array}$ & $\begin{array}{l}\text { Explanatory } \\
\text { variables }\end{array}$ & \\
\hline LOGSKILL & $(0.11)$ & LOWG & $0.21^{* * *}$ \\
LOGFIXCAP & $0.46^{* * *}$ & MEDG & $(0.13)$ \\
SOE & $(0.06)$ & & 0.1 \\
& -0.036 & HIGHG & $(0.09)$ \\
NSOE & $(0.83)$ & & $-0.49^{* * *}$ \\
FIE & $-0.21^{*}$ & EP1 & $(0.13)$ \\
& $(0.18)$ & & -0.07 \\
CONS. & $0.31^{*}$ & EP2 & $(0.09)$ \\
& $(0.13)$ & & 0.06 \\
Observations & $-0.48^{*}$ & & $(0.13)$ \\
Prob $>$ F & $(0.23)$ & & \\
$\overline{R^{2}}$ & 515 & & \\
\end{tabular}

Note: Level of significance $* 10 \% ; * * 5 \% ; * * * 1 \%$

The results show that coefficients of the capital intensity and wage level on firm competitiveness are very statistically significant and positive, indicating that they are the most important determinants. $1 \%$ increase in fixed asset and wage per employee leads to 0.73 and 0.46 percent increase in value-added created by an employee.

Both foreign and private ownership significantly impacts firm competitiveness but in contrasting directions, positive from the former and negative from the latter. It appears somewhat surprising at the negative coefficient for high-tech industry and the positive for low-tech correspondingly. Nonetheless, these reflect the fact that in Vietnam most manufacturing firms merely operate in the low-tech, low value-added stages in the production chains of industries internationally classified as the high-tech. Coefficient of firm environmental performance on firm competitiveness is not statistically significant, implying that there is uncertain impact of the former factor on the latter. Adjusted $R^{2}$ is 0.46 , indicating that the model has relatively high power of explanation.

\subsection{Discussion}

The paper adds characteristics of firm environmental performance by more ownership types to the existing studies that normally examine fewer of ownership types, five (Wang \& Jin, 2002, 2007; Wang \& Wheeler, 2005) or six (Jiang et al., 2014) albeit there exited a larger number (23) of ownership types in this studied transition country (Jefferson, Hu, Guan, \& Yu, 2002). All the thirteen firm types of ownership and three sector ownerships in Vietnam (Appendix 2.1) are analyzed in the paper with respect to both underlying aspects of environmental performance, solutions and results. In addition, this study is the first examining firm-level environmental performance indexed as being qualified by government and ISO 14001 certification while the existing studies use less direct indicators such as a number of government environmental inspection or intention of firm becoming ISO 14001- certified.

The paper is the pioneer using logistic panel model to analyze the determinants of environmental performance, as well as employing modified Cobb-Douglas function to examine its impact on firm competitiveness. This study's findings about those determinants support the previous literatures mentioned earlier by Dagusta et al. (2000), Lefebvre et al. (2003), Wang et al. (2007), Cole (2008). All of them reported the significantly positive impacts from firm size, EMS, foreign ownership, high-tech industries. But the results are not consistent with those by Wang et al. (2003) which found positive influence of private ownership in China, and the work by 
Earnahart and Lizal (2007) reporting positive role of the state ownership in Czech for environmental performance. These inconsistencies are most probably due to the varying economic and social context between Vietnam and comparative countries albeit all the three economies are in transition.

Going beyond the studies (Lefebvre et al., 2003; Wang \& Wheeler, 2005) that assessed the impact of a small number of manufacturing industries, this paper extends the existing literatures to characteristics of firm-level environmental activities and performances by combinations of three important aspects, ownership type, industry groups and age range. The paper also enlarges the scale of studies on environmental performance of manufacturing firms from several industries to three groups that cover respectively all 24 two-digit industries by ISIC Revision 3. The paper primarily assesses the role of number of environmental staff in greening growth of manufacturing firms, as well as categorizes firms' ages into three groups including the middle rather than only two groups, old and young or even only the old as were generalized and examined in the previous studies.

This study's result of an inconclusive influence of firm-level environment performance on firm competitiveness is also partly consistent with that by Lefebvre et al. (2003) finding insignificant correlation between firm environmental performance and competitiveness measured by cost reduction, revenue, management liability and firm image for three industries, printing, metal and wood products, but the positive significant association was found in the electric-electronic industry. This is most probably due to the differences between the two studies in all research aspects, scope, model, data type and method as is reviewed earlier. This paper's finding about environmental performance-competitiveness relationship is virtually in line with the work of Lopez-Gamero et al. (2009) which revealed an insignificant effect of firm's environmental performance on competitiveness indexed by cost competitiveness, also one of competitiveness indicator suggested by Porter $(1990,1998)$.

\section{Conclusions and Policy Implications}

The majority of manufacturing firms in Vietnam are SMEs, young, private owned firms and about half of all firms assigned environmental personnel and established EMS. Nonetheless, in general the environmental performance of the larger part of firms did not satisfy government requirements and only a small percentage met ISO 14001 standards. The factors positively affecting firm-level environmental performance were firm size, EMS, foreign ownership, number of environment staff, middle-age and high or medium-tech industries. In contrast, the constraints were private ownership, low-tech industries and young age. State-ownership, old age and medium-tech industry group had no significant impact on firm environmental performance at both national and international levels. There was no conclusive impact of firm environmental performance, whether being government or ISO 14001-certified, on firm competitiveness being assessed by labor productivity.

Given the low environmental performance of the majority of firms in Vietnam, especially for SMEs, private and young firms, by ISO 14001 standards. As well as no evidence of negative impact of environmental performance on firm competitiveness, further detailed policies need to be designed to effectively upgrade firm's environmental capacity. The first environmental policy package needs to focus on supporting SMEs, NSOEs, in particular the collective and private. The concrete policy measures support such firms in establishing EMS through corporate tax reduction or low-interest rate credit or in part subsidy. Furthermore, the policy should facilitate these firms in expanding size by capital, overcoming the cost barrier to SO 14001 registration, increasing reasonably the number of environmental staff and using more advanced, less pollution causing technology.

The second environment policy group should target the large firms and SOEs with more stringent regulations that require all of them to form and operate EMS within two years, and have to construct an appropriate plan to become ISO14001-certified to 2020, the year Vietnam was planned to become a largely industrialized country. Strengthening environmental performance of firms needs to be emphasized as an essential part of industrialization strategy and therefore environmental policy is designed in line with industrial policy.

\section{Acknowledgments}

The author would like to thank Vietnam National University (VNU) and University of Economics and Business for funding this research. This article is an outcome of a research project at VNU, Hanoi.

\section{References}

Ambec, S., Cohen, M., Elgie, S., \& Lanoie, P. (2011). The Porter hypothesis at 20: Can environmental regulation enhance innovation and competitiveness. Retrieved from http://www.rff.org/documents/RFF-DP11-01.pdf

Arimura, T., Hibiki, A., \& Katayama, H. (2008). Is voluntary approach is an effective environmental policy instrument: A case for environmental management systems. Journal of Environmental Economics and 
Management, 55, 281-293. http://dx.doi.org/10.1016/j.jeem.2007.09.002

Clark, T., \& Linzer, D. (2012, March). Should I use fixed or random effect? Retrieved from http://polmeth.wustl. edu/media/Paper/ClarkLinzerREFEMar2012

Clausen, J., Keil, M., \& Konrad, W. (2002). The relationship between competitiveness environmental performance and management of small and medium sized European manufacturing firms. Retrieved from http://www.ioew.de/uploads/tx_ukioewdb/IOEW_SR_168_

Cole, M., Elliott, R., \& Strobl, E. (2008). The environmental performance of firm: The role of foreign ownership, training and experiences. Ecological Economics, 65, 538-546. http://dx.doi.org/10.1016/j.ecolecon.2007. 07.025

Commission for Environmental Cooperation. (2005). Successful Practices of Environmental Management System in Small and Medium Size Enterprises: A North American Perspectives. Montreal. Retrieved from http://www3.cec.org/islandora/fr/item/2273

Dasgupta, S., Hettige, H., \& Wheeler, D. (2000). What improves environmental performance? Evidence from Mexican industry. Journal of Environmental Economics and Management, 39(1), 39-66. http://dx.doi.org/10. 1006/jeem.1999.1090

Earnhart, D., \& Lizal, L. (2007). Direct and indirect effect of ownership on firm-level of environmental performance. Eastern European Economics, 45(4), 66-87. http://dx.doi.org/10.2753/EEE0012-8775450403

GSO-General Statistical Office, Unpublished environmental session. Annual survey of total enterprises. 2007 -2009, Hanoi, Vietnam.

Hitchens, D. (2001). The implications for competitiveness of environmental regulations in the EU. Retrieved from http://ftp.jrc.es/EURdoc/AppendixS1.pdf

Hojat, A., Rahim, K., \& Chin, L. (2010). Environmental performance: A review of their determinants. American Journal of Economics and Business Administration, 2(3), 330-338. http://dx.doi.org/10.3844/ajebasp.2010. 330.338

Jefferson, G., Hu, A., Guan, X., \& Yu, X. (2001). Ownership, performance, and innovation in China's in large and medium-size industrial enterprise sector1. Retrieved from http://people.brandeis.edu/ jefferso/NBS China_Economic_Review.pdf

Jiang, L., Lin, C., \& Lin, P. (2014). The determinants of pollution levels: Firm-level evidence from Chinese manufacturing. Journal of Comparative Economics, 42(1), 118-142. http://dx.doi.org/10.1016/j.jce.2013. 07.007

Khanna, M., Deltas, G., \& Harrington, D. (2009). Adoption of pollution technique: The role of management system and regulatory pressures. Environmental \& Resource Economic, 44(1), 85-106. http://dx.doi.org/ 10.1007/s10640-009-9263-y

Lall, S. (2003). Assessing industrial competitiveness: How does Singapore fare. In R. Rajan (Ed.), Sustaining competitiveness in the new global economy. Cheltenham, Northampton, MA: Edward Elgar Publishing.

Lefebvre, E., Lefebvre, L., \& Talbot, S. (2003). Determinants and impacts of environmental performance in SMEs. R\&D Management, 33(3), 263-283. http://dx.doi.org/10.1111/1467-9310.00297

Lopez-Gamero, M., Molina-Azorin, J., \& Claver-Cortes, A. (2009). The whole relationship between environmental variables and firm performance: Competitive advantages and firm resources as mediator variable. Journal of Environmental Management, 90(10), 3110-3121. http://dx.doi.org/10.1016/j.jenvman. 2009.05.007

Mabey, N., \& McNally, R. (1999, March). Foreign direct investment and the environment: From pollution havens to sustainable development. A WWF-UK Report. Retrieved from http://www.oecd.org/investment/ mne/208 9912.pdf

Nakamuka, M., Takahashi, T., \& Vertinsky, I. (2001). Why Japanese firms choose to certify: A study managerial responses to environmental issues. Journal of Environmental Economics and Management, 42(1), 23-52. http://dx.doi.org/10.1006/jeem.2000.1148

National Center for Socio-Economic Information and Forecast. (2014). Báo động ô nhiếm môi truờng tại các khu công nhiệp ở Việt nam. Retrieved from http://www.ncseif.gov.vn/sites/vie/Pages/baodongveonhiemmoi -nd-16538.html 
Porter, M. (1990, 1998). The Competitive Advantage of Nations. New York, NY: The Free Press.

Porter, M., \& Linde, C. (1995). Toward a new conception of the environmental-competitiveness relationship. Journal of Economic Perspectives, 9(4), 97-118. http://dx.doi.org/10.1257/jep.9.4.97

Potoski, M., \& Prakash, A. (2006). Green club and voluntary governance: ISO 14001 and firm regulatory compliance. America Journal of Political Science, 49(2), 235-248. http://dx.doi.org/10.1111/j.0092-5853. 2005.00120.x

Potoski, M., \& Prakash, A. (2013). Do voluntary program reduce pollution? Examining ISO 14001 effectiveness across countries. Policy Studies Journal, 41(2), 273-294. http://dx.doi.org/10.1111/psj.12017

Prakash, A., \& Potoski, M. (2006). Racing to the bottom? Trade, environmental, governance and ISO14001. America Journal of Political Science, 50(2), 350-364. http://dx.doi.org/10.1111/j.1540-5907.2006.00188.x

Ruiz-Tagle, M. (2006). What are the determinants of environmental compliance in the Chilean manufacturing industry? A case study. Discussion Paper Series, Department of Land Economy, University of Cambridge. Retrieved from http://www.landecon.cam.ac.uk/repec/pdf/200617.pdf

Shadbegian, J., \& Gray, B. (2006). Assessing multi-dimensional performance: Environmental and economic performance. Journal of Productivity Analysis, 26, 213-234. http://dx.doi.org/10.1007/s11123-006-0017-3

Wang, H., \& Jin, Y. (2002). Industrial ownership and environmental performance: evidences from China. World Bank Research Working Paper. Retrieved from http://elibrary.worldbank.org/doi/pdf/10.1596/1813-9 450-2936

Wang, H., \& Jin, Y. (2007). Industrial ownership and environmental performance: Evidences from China. Environmental Resource Economics, 36(3), 255-273. http://dx.doi.org/10.1007/s10640-006-9027-x

Wang, H., \& Wheeler, D. (2005). Financial incentives and endogenous enforcement in China's pollution levy system. Journal of Environmental Economics and Management, 49(1), 174-196. http://dx.doi.org/10.1016 /j.jeem.2004.02.004

\section{Notes}

Note 1 . Since each dummy variable, EMS. GCERT, ISO takes the value of either 0 or 1 , the mean value of a variable is equal to the percentage of firm having corresponding action or observations taking value 1 .

Note 2. The selection of random is not based on normal Hausman test but due to informed limitations of the fixed model in this case: drop of most of observations, fail to investigate the impact of important dummy variable. In addition, the random model has several advantages compared to the fixed (Clark \& Linzer, 2012). The stationary is not a matter for a short, wide panel model. In particular, most variables of this model are the dummy taking only the value 0 or 1 . For the 2009 cross-session regressions (II), the robust is adopted to deal with possible heteroscedasticity.

\section{Appendix A}

Table A1. Characteristics of firm's environmental activities and performances by firm ownership, the 2007-2009 period

\begin{tabular}{lllll}
\hline $\begin{array}{l}\text { Firm } \\
\text { Ownership }\end{array}$ & $\begin{array}{l}\text { Firm } \\
\text { number }\end{array}$ & EMS & EP1 & EP2 \\
\hline Central SOE & 38 & 0.71 & 0.42 & 0.18 \\
& & $(0.46)$ & $(0.5)$ & $(0.39)$ \\
Local SOE & 37 & 0.7 & 0.62 & 0.14 \\
& & $(0.46)$ & $(0.49)$ & $(0.35)$ \\
Central limited SOE & 31 & 0.66 & 0.53 & 0.13 \\
& & $(0.48)$ & $(0.51)$ & $(0.34)$ \\
Local limited SOE & 15 & 0.67 & 0.67 & 0.13 \\
& & $(0.49)$ & $(0.49)$ & $(0.35)$ \\
Limited with $>50 \%$ & 204 & 0.67 & 0.56 & 0.18 \\
\hline
\end{tabular}




\begin{tabular}{|c|c|c|c|c|}
\hline $\begin{array}{l}\text { Firm } \\
\text { Ownership }\end{array}$ & $\begin{array}{l}\text { Firm } \\
\text { number }\end{array}$ & EMS & EP1 & EP2 \\
\hline state capital & & $(0.47)$ & $(0.5)$ & $(0.38)$ \\
\hline SOE & 325 & $\begin{array}{l}\mathbf{0 . 6 7} \\
(0.47)\end{array}$ & $\begin{array}{l}\mathbf{0 . 5 5} \\
(0.5)\end{array}$ & $\begin{array}{l}\mathbf{0 . 1 6} \\
(0.37)\end{array}$ \\
\hline Collective & 26 & $\begin{array}{l}0.27 \\
(0.45)\end{array}$ & $\begin{array}{l}0.27 \\
(0.45)\end{array}$ & $\begin{array}{l}0 \\
(0)\end{array}$ \\
\hline Private & 348 & $\begin{array}{l}0.12 \\
(0.33)\end{array}$ & $\begin{array}{l}0.21 \\
(0.41)\end{array}$ & $\begin{array}{l}0 \\
(0.05)\end{array}$ \\
\hline Private limited & 850 & $\begin{array}{l}0.41 \\
(0.49)\end{array}$ & $\begin{array}{l}0.42 \\
(0.49)\end{array}$ & $\begin{array}{l}0.05 \\
(0)\end{array}$ \\
\hline Joint-stock without state capital & 281 & $\begin{array}{l}0.64 \\
(0.48)\end{array}$ & $\begin{array}{l}0.49 \\
(0.5)\end{array}$ & $\begin{array}{l}0.12 \\
(0.33)\end{array}$ \\
\hline Joint-stock with $<50 \%$ state & 243 & $\begin{array}{l}0.58 \\
(0.5)\end{array}$ & $\begin{array}{l}0.48 \\
(0.5)\end{array}$ & $\begin{array}{l}0.13 \\
(0.34)\end{array}$ \\
\hline Non-SOE & 1748 & $\begin{array}{l}\mathbf{0 . 4 1} \\
(0.49)\end{array}$ & $\begin{array}{l}\mathbf{0 . 4} \\
(0.49)\end{array}$ & $\begin{array}{l}\mathbf{0 . 0 7} \\
(0.25)\end{array}$ \\
\hline $100 \%$ Foreign & 773 & $\begin{array}{l}0.6 \\
(0.49)\end{array}$ & $\begin{array}{l}0.62 \\
(0.49)\end{array}$ & $\begin{array}{l}0.19 \\
(0.39)\end{array}$ \\
\hline Joint-venture with SOE & 120 & $\begin{array}{l}0.64 \\
(0.48)\end{array}$ & $\begin{array}{l}0.59 \\
(0.49)\end{array}$ & $\begin{array}{l}0.23 \\
(0.42)\end{array}$ \\
\hline $\begin{array}{l}\text { Joint-venture with } \\
\text { Non-SOE }\end{array}$ & 70 & $\begin{array}{l}0.44 \\
(0.5)\end{array}$ & $\begin{array}{l}0.49 \\
(0.5)\end{array}$ & $\begin{array}{l}0.19 \\
(0.39)\end{array}$ \\
\hline FIE & 963 & $\begin{array}{l}\mathbf{0 . 5 9} \\
(0.49)\end{array}$ & $\begin{array}{l}\mathbf{0 . 6 1} \\
(0.49)\end{array}$ & $\begin{array}{l}\mathbf{0 . 1 9} \\
(0.4)\end{array}$ \\
\hline Total & 3036 & $\begin{array}{l}\mathbf{0 . 4 9} \\
(0.5)\end{array}$ & $\begin{array}{l}\mathbf{0 . 4 8} \\
(0.5)\end{array}$ & $\begin{array}{l}\mathbf{0 . 1 2} \\
(0.32)\end{array}$ \\
\hline
\end{tabular}

Source: Author's own calculation based on GSO firm-level environmental survey

\section{Copyrights}

Copyright for this article is retained by the author(s), with first publication rights granted to the journal.

This is an open-access article distributed under the terms and conditions of the Creative Commons Attribution license (http://creativecommons.org/licenses/by/3.0/). 